\title{
The Architect's Dilemma: A Self Reflection in Understanding Prison Design and Construction in Private Prison Projects
}

Giustina G S Consoli (School of Commerce, University of South Australia, City West Campus, North Terrace, Adelaide, South Australia, Australia)

\section{ABSTRACT}

Australia embarked upon a number of private prison projects during the 1990's. These projects involved the competitive bidding for prison projects by consortia, which generally consisted of a correctional operator, contractor and architect. The architect's role in such projects was to satisfy the needs and desires of the operator, contractor and government assessors. As a result, the architect became a critical element in the successful delivery of the prison projects.

Intensive intervi ews with such architects have shown that a number of issues were experienced as a result of their inclusion in the projects. These architects reported: (a) uncertainty in undertaking large specialist projects, (b) grappling with their own expectations and those of other participating parties as to the role of the prison architect, (c) a desire to acquire a working knowledge of the philosophies of incarceration and prison design and construction, and (d) difficulties in working within an environment where suspicions were raised in regards to conflicting and underlying objectives of the operators and contractors.

Keywords:Prison Design and Construction; Design and Construct; Procurement;

Privatisation, Architect.

\section{INTRODUCTION}

Only a few academic investigations have specificaiiy examined the roie of the contemporary prison architect and influences upon them. Some most notable accounts include Atlas 1982; Atlas \& Dunham 1990; Derbyshire 2000; Johnston 1973, 2000 and Fairweather 1994, 2000a. There are also suggestions that the role of the prison architect is dictated by the forces created by differing delivery methods (Knape! 1993; Dixon 1993; Cunningham 1999).
This paper presents architect views regarding their inclusion and role as prison architects within private prison projects in Australia, spanning between 1985-2000. A total of 22 architects that participated in private prison projects were interviewed via use of semi structured interview questionnaires (Consoli 2003, 2004). This paper reviews:

a) Literature that exposes perceptions regarding the role of the prison architect and the potential impact of privatisation;

b) Contractual relationships between parties in private prison projects; and

c) Responses by architects in regards to participating in the prison projects.

Interviews highlighted that the architect's inclusion in the prison projects, and their understanding of their role and of prison design and construction, were considered critical issues in the experiences of architects in the private prison projects. As such, the principal themes to emerge are the role of the architect in design and construct teams, and the impacts this places upon the architect in the prison design process. In effect, the findings of the study highlight the erosion the architect's authority in prison design projects, and the effect of private prison projects in fast tracking this process.

\section{CONSIDERING THE PRISON ARCHITECT}

From Jeremy Bentham's Panopiicon prisoii fmm and theoretical stance, to the seminal works of Michel Foucault's Discipline and Punish and Robert Evan's The Fabrication of Virtue: English Prison Architecture, 1750-1840, the emergence of the prison as a modern institution in the West has raised great debate. However, this has also meant that the role of the prison architect and the development of prison architecture as a specialist area has received scholarly attention. Literature regarding modern prison design and 
the role of the architect highlights a number of themes. This section provides a snapshot of such views.

Various commentators report that the role of the contemporary prison architect has altered from one who assumed a relatively central authoritative position in the past, to one who, in their attempts to satisfy the various forces and protagonists in prison delivery, has been forced into a more submissive role (Atlas 1982; Atlas \& Dunham 1990; Derbyshire 2000; Johnston 1960, 1973, 2000; Fairweather 1989, 1992, 1994, 2000a, 2000b).

Another area of discussion has focussed upon the methods employed in the selection of architects for prison projects. For instance, Farbstein (1986) reported that the architect should be assessed against selection criteria. She added that this would typically include correctional experience and a review of their previous work. Other criteria include the size of their firm, ability to establish rapport with the clients, and assistance from their consultants to undertake the prison projects. Englar (1987) believed that it is the prison owner's responsibility to $\cdot . .$. select the most qualified team, pay a fair fee, and reap the benefits of an adequate planning and design process' (Englar 1987, p.33).

Difficulties faced by architects have also been widely reported. Although attempts to standardise correctional design has been a means to give architects guidance, architects in tum have reported being smothered by conflicting and stringent requirements (Atlas 1983; Fillip 1985; Atlas \& Dunham 1990; Summers et a/1996; Fairweather 1994, 1995, 2000b). This has left their role and resultant product a contentious issue. This has been evident on a number of levels. According to Atlas \& Dunham (1990):

Architects often contribute to prison problems. These planners often do not understand inmate characteristics and their needs and therefore design facilities on the basis of information from a third party, on some general impression of inmates (Atlas \& Dunham 1990, p. 55).

Likewise, Fairweather (2000b) maintained:
The perennial task of prison architects is to struggle to produce acceptable solutions in a very different and changing climate of opinion amid conflicting advice (Fairweather 2000b, p.61).

Fairweather (2000) advocated the need for the specialist prison architect. He also warned that alternative procurement would inevitably reduce the architect's role. He maintained that it would be difficult for architects to question their 'sponsors' within a competitive framework. Fairweather (2000a) stated that the fact that '...managing design has never been treated with the same seriousness as other aspects of prison design (2000a, p.66), and that $\cdot$....architects are not encouraged to enter into any sort of meaningful discussion about the wider purposes of imprisonment and attitudes of society" (2000a, p.66), meant they would be rendered an irrelevant inclusion with consortia led prison projects.

This is closely related to the perception of prison architecture as a separate and distinct area of architecture, which has encouraged the belief that greater focus and responsibility should be directed at prison design and construction processes (Atlas 1990; Nadel 1996; Dietsch 1997; Johnston 2000). McConville (2000) extended this point further and claimed that the combination of competition/privatisation and prison architecture is unhealthy and fraught with limitations. This trend is considered a detriment to prison design processes, the role of the architect, and the built form.

Whilst the role and experiences of the architect and other design professionals has generally avoided mainstream attention, a most recent development is the Prison Design Boycott Campaign (ADPSR 2004) in the United States. This boycott has resulted in a wave of architects, designers and planners collectively refusing to undertake prison projects. The movement seeks to increase discussion of alternatives to prisons, and encourage public debate and legal reform (ADPSR 2004; Finoki 2005; Garofoli 2005; Fuss 2006; Yoders 2006).

\section{PRIVATE PRISON PROJECT CONTRACTUAL ARRANGEMENTS}

The contractual arrangements in the private projects saw the inclusion of alternative 
procurement methods (Russell \& Abdel-Aziz 1997) in Australian prison delivery. In such projects the private sector was placed under a contractualobligation to finance, design, construct, operate and maintain the facility for a set time (Cunningham 1999).

The delivery methods used in the Australian projects can be typified as Design and Construct, however variants include BOT (Build Operate Transfer), BOOT (Build Own Operate Transfer) and DCFM (Design Construct Finance Manage). The resulting contractualrelationship between the parties typically saw the private correctional company (operator) as owner. They contracted with a single building contractor who, usually together with the operator, selected an architect. The architect contracted directly to the contractor. It was the contractor's responsibility to provide all design and construction services. The contractor also led the consortia in regards to the design and construction component of the bid, and throughout the design development and contract documentation (Knapel 1993;

Cunningham 1999).

Various studies have reviewed the successes and failures of using alternative delivery methods, primarily from a non-prison design and construction perspective. Such research has shown variable impacts upon the role of designers/architects in relation to the choice of delivery method. Some notable findings include that:

- Project managers would ultimately steer and control new building delivery methods and pursue different criteria to architects (Lockley 1988; Hawk 1996; Emmitt 1999);

- Cost imperatives, cultural and interdisciplinary differences of project participants, and communication issues strained relationships between parties and caused friction and jeopardised project success (Akintoye \& Skitmore i992; Latham i994; Loosemore, Haii \& Dainty 1996; Jefferies \& Chen 1999; Phua \& Rowlinson 2003; Lam, Chan \& Chan 2003);

- Lack of knowledge regarding construction processes and expectations excited participants (Battersby \& Yates 2003);
- Possible scope for innovative improvements arising from alternative delivery methods (Kumaraswamy \& Dulaimi 2002; Harding 1997); and

- Adoption of new skills, roles, responsibilities and risks, so that all phases of a projects lifecycle can be managed effectively (Love et a/2000).

In regards to prisons, Design and Construct has been considered an alternative delivery method, which has an impact upon the roles and responsibilities of the parties (Knapel 1993). Typically, the contractor is ....responsible for managing and coordinating all aspects of design and construction to complete the project within the specified time and cost limits (Knapel 1993, p. 9). Knapel (1993) added that:

...because the architect in this method works for the design/build contractor rather than for the owner approval milestones are minimised, the contractor has opportunities to overlap phases...because the architect in this method works for the design/build contractor rather than directly for the owner, contract provisions for owner input and the opportunity to review the design may become very important....however as a subordinate to the contractor, the architect may be inclined to be primarily faithful to the time and cost interests of the contractors team (Knapel 1993, p.10).

Englar (1987), acknowledging the shortcomings of the design and construct methods, also stated that:

Architects believe that nothing should be done to compromise the interactive process that should occur between the operator...and the designer. Programming and design of a typical jail or prison requires professional expertise in all parts of the facility...therefore, it is important that the design be ihoughtfuiiy and refiectiveiy planned through the interaction of the architects and the owners and operators (Englar 1987, p.32).

Dixon (1993) found that private operators believed the use of alternative procurement methods meant a '....different kind of architect (Dixon 1993, p.6) was required. Such an 
architect would not possess a traditional mindset but be open to new and innovative approaches. Dixon (1993) considered this as imperative for those architects involved in the delivery of a private prison. The role of the architect has continued to create some discussion. In one instance, the government maintained that there was an unequivocal reliance upon architects, and that '...you take the advice of the architects... these people are skilled in designing prisons' (Owen 1998). However, it is the architect's voice that remains to be heard regarding their role and expectations in prison design and construction.

This paper is focussed upon the role and constraints faced by the consortia architect in Australian private prison projects. This is highlighted in two principal themes: Part 1 -The Architect in Design and Construct Tearns and Part 2 - Understanding Prison Design and Construction.

\section{PART 1: THE ARCHITECT IN DESIGN AND CONSTRUCT TEAMS}

\section{SELECTION OF ARCHITECTS}

All architects expressed that prison design was not an area they would normally have pursued, with most believing they had '...got into it by accident...'. Experienced architects argued that a failure of many consortia teams was the fact that '...prisons don't attract the best architects in the world...'. The other failure was the method of selecting architectural firms by consortia. Architects expressed that the selection of architectural firms by private prison consortia was neither predictable nor logical. The predominant belief was that selection was based upon their previous affiliation with the public sector. They likewise stated that such experiences had forged them a reputation in prison design; hence their recruitment into private projects meant that the private consortia wished to draw upon this knowledge. In other instances, architects were unsure of why they were chosen. Such architects had limited, if any, experience in correctional design. They surmised that their inclusion in the prison projects was because they had worked with the consortia contractor in other projects. Both experienced and inexperienced architects considered their selection as '...lucky...' and a sign of being '....well-liked...' by the contractor.
For all architects, selection was considered an honour.

All architects expressed initial excitement at entering prison design and construction. However, they were equally concerned at their lack of knowledge and expressed uncertainty of what was expected in correctionaldesign. It was reported that limited pre-design research had been independently conducted, which caused most inexperienced participants to be '... personally terrified...'. In contrast, those deemed experienced and knowledgeable of State projects believed that their skills could be easily transferable with only a '...minor adjustment...' to meet private sector requirements.

Architects also showed respect and admiration towards operators. They found '... most private company people are above board and ethical...', and generally supported the motivations and outcomes pursued by the private prison operators. Ultimately, all architects believed that the operator '....wouldn't get involved in something that wasn't straight up and down...'.

\section{ROLE OF THE ARCHITECT}

Architects considered that their role differed according to their experience in prison design and construction, the State and the consortia they worked with. Architects also expressed that their role could fluctuate greatly from one project to another due to uncontrollable factors, such as changes of key personnel or differences in delivery methods.

All architects expressed that their role was more than to '...just do one's bidding...'. They believed they assumed a greater responsibility, which included responding to community sentiment, producing appropriate buildings and environments, and to delve into the complex area of prison design and construction. Their success at achieving such objectives was not measured in terms of the outcome of a bid; it was based upon their own personal value judgements of the process. Hence, it was common to find successful bids were not always considered a satisfactory outcome of the process. This was prevalent when the architect believed that they had been denied valuable input, control, or the capacity to achieve a required level of understanding. 
Reports also emphasised the belief that the '....architects role is to try and understand the brief... . . This meant a number of objectives had to be met. Architects were to '...evolve... and develop the brief...' and to '...try to design for the clients' true needs, and not necessarily what they want...'. Furthermore, all consortia architects believed that their ultimate role was to help the government break from tradition or ....past moulds...'. All affirmed that they were an Instrument for the development and incorporation of innovation. Although the issue of innovation was of priority in assessing expectations and distinguishing between teams and professions, it was also a point of contention, often dividing consortia architects.

Although there were a number of issues that developed amongst parties within consortia, generally all architects reported an atmosphere of maraderie relat1on to the early stages of the bidding process, architects reported that since '...everyone has the same objective...', it meant everyone would '....work together united...'. This was manifested in a hands-on approach, in which architects would '....get into the clients' heads, and try to understand all the stakeholders needs...'. Most architects believed that the operator fully comprehended their role. They maintained that the operator was dependant upon them, adding '...they (operator) ought to be, if they want to win...'. Since architects considered themselves as the sole party with the abilities to give the operator -...the edge based on their philosophy...', they considered themselves both indispensable and an integral part in the bid process.

Reg?rdless of their level of prison experience, arch1tects also demonstrated a desire to improve themselves with every project. Hence, they undertook a constant review of prisons from every project and consortia. Although they were legally restricted from accessing the schemes of competitors, this was rarely considered a barrier. rnoeeo, 't' nose arcrúteets given an opportunity to compare their schemes with others wanted '...to see if they (the opposition) have any advantage...'. This was predominately the case with architects who had worked on a number of projects. In contrast, architects of limited correctional experience were entirely reliant upon the operator and contractor, hence demonstrated little concern at comparing schemes. As '....novices to the game....', they assumed the operator and contractor would have done such investigations, and would simply brief them of their requirements.

\section{RELATIONSHIPS RAISING SUSPICION}

Most architects believed contractors had become progressively nervous during design development and contract documentation. They sensed contractors believed that the architect would be '...pushing the operators advantage to the disadvantage of the construction company...'. Consequently, architects believed contractors had become excessively suspicious of their actions and motivations.

Architects reportedly felt sandwiched between the requirements and orders of the contractor the need to achieve and maintain the best interests of the operator, and their ....moral sense of the greater good of the facility...•. All ar hitects try1ng to support your client, not screw your client .... This sentiment seemed to aggravate their rela ionship felt ...left sort of cloak and dagger giving advice to both parties...'. As the projects developed, and relationships between parties evolved and deepened, the level of suspicion escalated.

Responses demonstrated two reasons for the cause of such unrest. Firstly was the affect of contractor experience in prison projects. Architects were suspicious of contractors who lacked prison-building experience. In cases where experienced architects were teamed with first time prison contractors, architects believed they had greater knowledge of the key issues in prison design and construction; hence they should have had ultimate decision-making authority. For instance:

\footnotetext{
...There are not many prisons built in Australia, and there was no builder in Australia that could really put up his hand and say they are prison buildina exoerts...so it's a little frustrating that the architects in the whole design team are being frustrated by people that really didn't know what they were doing...
}

All.architects expressed that a prison project is a un1que and specialised building, which requires greater levels of thought and consideration. The majority of architects complained that contractors 
did not possess the required level of theoretical understanding. Architects believed that '... the builder can't understand what incarceration means, and what it means to be housed inside...'. They believed since contractors lacked such understanding, they would try to handle prison projects as any other construction project, which was considered a '... dangerous approach...'. For instance:

\begin{abstract}
...For the builder, it's a matter of putting a prison together and moving on...it might be a prison...it might be a hospital...horse stable...they couldn't care less ...it's like: 'Give me a set of standards mate, and we will build you a prison'...
\end{abstract}

An architect of an opposing consortium agreed, stating:
...They (contractors) don't have the slightest idea of what constitutes a prison. They wouldn't know a prisoner can tear 1.6 mil steel.. .they don"t even think about a prisoner urinating on something untilit corrodes away...you really have to be skilful in anticipating what they might do if they wish to create mischief...

Architects expressed concern that early in projects, contractors began to ....change...', and take the schematic design and design development '...hostage...'. They believed this was directly related to the second cause of unrest - the procurement method. The restrictions imposed by the contractors were, according to architects, primarily because contractors were at the helm of decision-making, yet were too inexperienced to satisfactorily assume such responsibility. Architects believed it was the contractor's obsession with financial issues, which caused problems to arise. While some simply regarded this as '... financial naivety by contractors...', others found this a calculating ploy by contractors to maximise profits. This architect explained further:

... I think the reason for that is that regardless of their advertising materials, builders say whatever they have to say to win a job...builders instruct their teams that: "We have tendered for this price, but we must deliver the job for less than this...unless you can work the price up on variation...you must make a margin on this job'. Despite all the rhetoric and the salesmanship in winning the contract, every contract has exactly the same problem...

This resulted in parties within consortia possessing different objectives. It became evident that while the contractor's decisionmaking was based upon the minimum costspatial requirements, architects believed they had to pursue a balance between costing and theoretical responses, which they considered would be to the overall benefit of the facility and its users.

Architects also agreed that Design and Construct procurement forced the government to seek a '...packaged product...' and thus avoid addressing problems with the individual components of the package. Architects considered this inappropriate because it meant assessors were judging consortia '...cosmetically....', and with an overemphasis upon consortia '...make-up...'. Most architects believed that this was the catalyst for uncertainty and speculation, and that assessor's reactions to personnel within consortia had a greater impact than the design and proposal itself. As a result, architects believed the design process had been undermined by the Design and Construct contractualarrangements. Hence, all architects concluded that consortium parties '...would probably be better off getting a design prepared by an architect with a team of consultants working for the operator...'. This architect summarised this problem in the following extract:

...The difficulty we have as designers in such a situation is that not only do we have to produce an efficient design when we join a consortium, we have to have the 'right' operator, and the most cost driven builder, and the most aggressive funder. The designers are way down the food chain, unable to gain any entrepreneurial dividend, yet critical to the process. BOOT schemes are high risk, high cost, and don't necessarily provide architects with a lead role in design...quite the opposte, as you are going to be compromised in reducing design concepts due to the cost, and less likely to innovate due to the committee perceptions of joint risk. Unfortunately, this type of bid is becoming more prevalent, and there appears to be no counter movement to invest in design solutions, and then to go to the market... 


\section{PART 2 UNDERSTANDING PRISON DESIGN AND CONSTRUCTION}

All architects believed it was important to comprehend the correctional philosophy of the State and the operator. Of equal importance did the need for a philosophical understand of incarceration, punishment, and of what alternatives were available. In all projects, architects relied on a verbal articulation of consortia and the State correctional philosophy by the operators. This was reportedly because operators did not have a published philosophical stance, and hence preferred to rely on verbal discussions. Architects reasoned that the inability to document philosophical stances indicated that consortia preferred the flexibility of oral reporting. They believed this enabled the operators to change their philosophy; perhaps as a response to a particular project or the State they were working within. Indeed, architects reported State or operator stances could differ markedly from one project to another. Hence, architects were aware that regardless of how many projects they completed with an operator, it was critical that a philosophical briefing was given for every project.

Attempts at understanding correctional philosophies frustrated architects. Although all architects recommended the need to engage in philosophical debate, and to '...thrash out philosophy..', all unanimously expressed disappointment with the detail and content of the philosophy. Experienced architects elaborated that there is a need to be at '.... ease with the philosophy that is driving the design decisionmaking, otherwise you don't feel good as an architect...'.

A perceived lack of substantial philosophical direction was said to hamper a fluid approach to the design process. A minority of architects believed the inability to discuss issues on a broader level was because operators were aware that it could have a dramatic affect on the physical form of the building. The remainder believed addressing the broader issues was hindered by a number of underlying forces, including individual personalities, unsaid objectives of the operator, and the dynamics created by the consortia environment.

Perhaps as a result of such frustrations, it was common for architects to clash with operators later in the bidding process. Arguments arose when architects demanded additional explanation or suggested changes in approach. Most architects believed that the cause of such friction was the operator's failure to move outside their established comfort zone. Architects also believed failures at gaining a required level of information was due to forces including economic objectives, the design brief, and the contractor's professional and personal imperatives.

\section{DISCUSSION AND CONCLUSION}

The private prison case study supports current literature that finds that the role of the modem prison architect has been diluted and creates frustration, uncertainty, and may adversely impact upon the product itself (McConville 2000; Fairweather 2000a, ADPSR 2004).

The study showed that architects questioned what their role was in the prison projects. They believed that their responsibilities as architect fluctuated subject to individual project requirements, the tum over of key personnel, and the specific requirements of the delivery method. According to architects, the responsibilities within consortia included responding to community sentiments regarding appropriate prison facilitation, producing appropriate buildings and environments, and "understanding" prison design and construction. As highlighted by Fairweather (2000b), and supported in the study, the strain experienced by architects stemmed from their belief that they had a responsibility to understand and articulate the brief, so that they could evolve the bri ef to meet client needs, help the government break from tradition, outdated prison designs and construction methods, and develop and incorporate innovation in their schemes. However, as the delivery of projects have changed and the role and authority has likewise been diluted (as per Atlas 1990; Nadel1996; Dietsch 1997; and Johnston 2000), the ability to incorporate and achieve best practice as articulated by prison architectural commentators such as Farbstein (1986) is also evidently reduced.

Whilst literature has hinted at the possibility that a move towards alternative delivery is a catalyst for the diminished role of prison architects (McConville 2000), this study indicates that it plays a fundamental role. The study showed that at both the bidding stage and assessment of 
bids architects felt an uncomfortable level of suspicion and distrust between parties which undermined some relationships. Architects generally believed that they were sandwiched between the contractor's requirements and the interests of the operator. They resolved that such tension arose primarily due to the use of alternative delivery methods. This demonstrated that the delivery method created an unsuitable arms length approach between consortia and the government, enabled the inclusion of inexperienced contractors, and allowed contractors to take control and effectively manipulate the process for their own individual gains.

Thus supporting Atlas \& Dunham 1990, Derbyshire 2000, Johnston 2000 and Fairweather 2000a, 2000b, the architects were forced into a more submissive role. In addition, as per general construction project literature (such as Akintoye \& Skitmore 1992, Jefferies \& Chen 1999 and Lam, Chan \& Chan 2003), the study also showed that resulting tensions in prison projects were symptomatic of parties from different disciplines and educational/training backgrounds forcing upon them values, which they.believed were inappropriate. Consequently, arch1tects recommended that there is a need to fully understand consortia philosophy, and initiate and continually encourage philosophical debate amongst parties within consortia, between the private and public sector, and the community at large.

Ultimately, the study shows that the architects believed that their role was to improve established prison design, and achieve better outcomes, yet had been prevented from doing so. It is not surprising that such sentiments have now led to the movement in the United States for architects to boycott prison projects (ADPSR 2004; Finoki 2005; Yoders 2006). Indeed, it may also be indicative of a more general diminishing role of the architect in modem times, in which the private prison experience simply serves as a case study for a much wider developing issue.

\section{REFERENCES}

ADPSR (Architects/Designer/Planners for Social Responsibility). (2006), Prison Design Boycott Campaign - About this Campaign, http://www.adpsr.org/prisons/index.htm, accessed April 2006.
Akintoye, A \& Skitmore, S. (1992), 'Pricing Approaches in the Construction Industry'. Industrial Marketing Management, vol. 21, pp. 311-318.

Atlas, R. (1982), Correctional Architecture: Violence and Architectural Determinism, PhD Dissertation, University of Florida.

Atlas, R. \& Dunham, R. (1990), 'Are Prisons Any Better? Twenty Years of Correctional Philosophy'. Changes in Prison Facilities as a Function of Correctional Philosophy, US, Sage Criminal Justice System Annuals Publications.

Atlas, R. \& Dunham, R. (1990), 'Are Prisons Any Better? Twenty Years of Correctional Philosophy'. Changes in Prison Facilities as a Function of Correctional Philosophy, US, Sage Criminal Justice System Annuals Publications.

Battersby, L. C \& Yates, J. K. (2003), 'Designer Construction Knowledge and its Effects', Construction Research Congress, Winds of Change: Integration and innovation in Construction, Proceeding of the Congress, pp.77-84.

Consoli, G.G.S, (2003), 'Prison Architecture and Privatisation - Project Delivery in the Australian Context', PhD Thesis, School of Architecture and Building, Deakin University, Victoria, Australia.

Consoli, G.G.S (2004), "Conducting an Ethnomethodological Study for the Comparison of Private and Public Prison Delivery Processes in Australia', Journal of Construction Procurement Vol. 10, No. 1, May 2004.

Cunningham, H. (1999), Private Sector Provision of Public Infrastructure: A Case Study -Acacia Prison, School of Architecture, Construction and Planning, Perth, Western Australia, Curtin University of Technology.

Dietsch, D. (1997), "Jailhouse Blues: The Boom in Prison Construction Raises Ethical Questions for Architects', Architecture, October, Issue. 86, p.11. 
Dixon, P. D. (1993), 'Correctional Facilities', Progressive Architecture, vol. 74, no. 2, p. 51.

Derbyshire, A. (2000), 'Architects and the Prison', Prison Architecture: Policy, Design and Experience, Leslie Fairweather and Sean McConville (ed), UK, Architectural Press.

Englar, R. L. (1987) The Costs of Design and Construction', in Constructing Con-ectional Facilities: Is there a Role for the Private Sector? The Brookings Institution, Washington, D.C. USA.

Evans, R. (1982), The Fabrication of Virtue: English Prison Architecture, 1750-1840, Cambridge University Press, New York.

Fuss, T. (2006), 'Rethinking Prison Design', in LA Architect Magazine, http://www_adpsr.org/prisons/LAArchitect prison s June06.pdf, accessed July 2006.

Johnston, N. \{1973), The Human Cage: A Brief History of Prison Architecture, Philadelphia, The American Foundation.

Johnston, N. (2000), Forms of Constraint: A History of Prison Architecture, Illinois, University of Illinois.

Farbstein, J. (1986), Correctional Facility Planning and Design, Van Rostrand Reinhold Company, US.

Fairweather, L. \{1989), 'Prisons: A New Generation", Architects Journal, 15 March 1989, pp. 26-31.

Fairweather, L. (1992), 'Prisons', Architects

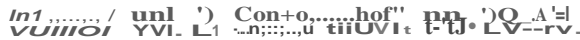

Fairweather, L. (1994), 'Prison Design in the Twentieth Century', Architecture of Incarceration, I. Spens (ed), Academy Editions, UK.

Fairweather, L. (2000a), 'Does Design Matter'?, Prison Architecture: Policy, Design and Experience, Leslie Fairweather \& Sean
McConville (ed), Great Britain, Architectural Press.

Fairweather, L. (2000b), "Public / Private Partnerships', Prison Architecture: Policy, Design and Experience, Leslie Fairweather \& Sean McConville (ed), Great Britain, Architectural Press.

Finoki, B. (2005), 'De:constructing Recidivism' in Archinect, 25 April 2006, http:1/archinect.com/features/article.php?id=1821 $20230 \mathrm{M}$, accessed June 2006.

Fillip, J. (1985), 'Public Client, Captive Space', Architecture California, March/April, pp. 30-33.

Foucault, M. (1977), Discipline and Punish: The Birth of the Prison, Penguin Books, London.

Garofoli, J. (2005), 'Just Say No to Prison Jobs, Architect Urges Colleagues, He says Ethics Demand Jail-Design Boycott', San Francisco Chronicle, May 3, 2005.

Jefferies, M. C \& Chen, S. E. (1999), Education for Sustainability - Strategic Approach on Construction Management, Trends in Construction Management Education and Responsibility, Richmond, Built Environment Research Group, University Western Sydney.

Johnston, N. (2000), Forms of Constraint: A History of Prison Architecture, Illinois, University of Illinois.

Knapel, C. S. (1993), 'Project Delivery Options: An Introduction to Corrections Construction', National Institute of Justice: Construction Bulletin, August, Washington.

Lam, E.W.M., Chan, W.M \& Chan, A. P. C. (2003), 'Potential Problems of Running Design Build Projects in Construction', Transactions Hong Kong Institution of Engineers, vol. 10, no. 3.

Latham, M. (1994), Constructing the Team: Joint Review of procurement and Contractual 
Arrangements in the UK Construction Industry, London, HMSO.

Kumaraswamy, M \& Dulaim M. (2002),

'Empowering Innovative Improvements through Creative Construction Procurement', Engineering Construction and Architectural Management, vol. 8,no. 5/6, p.325-334.

Loosemore, M., Hall, K \& Dainty,A. (1996), Innovation and Courage in Construction Management Rseearch, Proceedings of the 1 ih ARCOM Conference, Sheffield Hallam University.

Love, P.E. D., Wood, B. M., Picken, D \& Confoy, B. (2000), 'The Privatisation of Correctional Facilities in Australia', Facilities, vol. 18, no.1, pp.56-65.

McConville, S.(2000), "The Architectural Realisation of Penal Ideas', Prison Architecture: Policy, Design and Experience, Fairweather Leslie and Sean McConville (ed), Great Britain, ArchitecturalPress, pp. 1-16.

Nadel, B. (1996), 'Prison Design - Elusive Opportunities in a Big Field', Architectural Record, March, pp.99-100.
Owen. K, (1998), 'Prison Flaws Fixed', Herald Sun, 22 July, Melbourne.

Phua, F. T. T \& Rowlinson, S. (2003), 'Cultural Differences as an Explanatory Variable for Adversarial Attitudes in the Construction Industry: The Case of Hong Kong', Construction, Management and Economics, vol. 2, no. 7, pp. 777-785.

Russell, A. D \& Abdei-Aziz, A.M. (1997), 'Public -Private Partnerships and Public Infrastructure'. Proceedings of the First International Conference on Construction Industry Development: Building the Future Together, National University of Singapore.

Summers, D., Richard, D., Nelson, J. \& Munhall, L. D. (1996), 'The Virtual Prison: What You See is What You Get', Corrections Today, April,pp. 106-108.

Yoders, J. (2006\}, "ADPSR President Claims AIA Censored Prisons Presentation', http://www.bdcnetwork. com/article/CA6342508.h tml?text=adpsr, accessed July 2006.Abd El Halim, O. A., and Haas, R. (2004). "Process and Case Illustration of Construction Innovation." Journal of Construction Engineering and Management, 130(4), 570-575. 